\section{Scientific Electronic Archives}

Issue ID: Sci. Elec. Arch. Vol. 13 (5)

May 2020

DOI: http://dx.doi.org/10.36560/13520201012

Article link

http://sea.ufr.edu.br/index.php?journal=SEA\&page=article\&o $\mathrm{p}=$ view\&path $\% 5 \mathrm{~B} \% 5 \mathrm{D}=1012$ \%path $\% 5 \mathrm{~B} \% 5 \mathrm{D}=\mathrm{pdf}$

Included in DOAJ, AGRIS, Latindex, Journal TOCs, CORE, Discoursio

Open Science, Science Gate, GFAR, CIARDRING, Academic Journals

Database and NTHRYS Technologies, Portal de Periódicos CAPES.

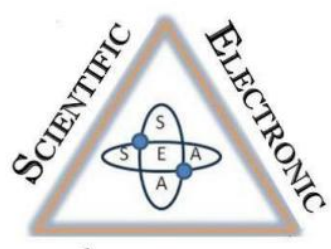

ArChives

ISSN 2316-9281

\title{
Processing of bamboo shoots
}

\author{
S. M. Dias, H. R. B. de Souza, R. Vera \\ Federal University of Goiás
}

Author for correspondence: sarahmd1011@gmail.com

\begin{abstract}
Brazil has a great interest in exploring its natural resources and connect it with sustainability. This research had as its main objective, exhibit the potentialities and possibilities of bamboo culture as a vector of sustainable development. The methodology used was set to the bibliographic survey of documents, scientific articles and available studies, directing over actions taken until the present date. Thus, indicating taxonomy, morphology, distribution, ways of propagation, cycle of life, the culinary focus of bamboo, general uses and applications, notably, its shoots. Therefore, understanding the various applications of bamboo, creating products of varying added value and the processing of bamboo shoots, with its vast potential in the food business by the appropriate techniques, generating several products of high nutritional value in general.
\end{abstract} Keywords: Sustainability, Potentialities and Possibilities of Bamboo Culture, Culinary Focus of Bamboo, Techniques, Nutrition Values.

\section{Context and Analysis}

Like other countries in general, Brazil has a great interest in exploring its natural resources and connect it with sustainability in order to keep future generations, enhancing the handling in the most diverse areas. Facing this vision, the National Policy of Incentives for Sustainable Handling and Bamboo Cultivation, known as PNMCB, is justified by the Law $12.484 / 2011$ in a way to recognize the importance of bamboo and its uses, regarding national development, contemplating the economic, social and environmental spheres of the activities of this culture (Brasil, 2011).

This research defines, as its main objective, to showcase the potentialities and possibilities of bamboo culture as a vector of sustainable development, as in the perspective of food safety. The methodology used was set to the bibliographic survey of documents, scientific articles and available studies, directing over actions taken until the present date.

In botany, species popularly known as bamboo encompass a cluster of herbaceous and woody plants that are part of the family Poaceae and the subfamily Bambusoideae, being amongst the monocotyledons. The bamboo is still held in two tribes: Olyreae e Bambuseae, totalizing 90 genus and
1100 species that are present in nature on every continent, except the European. (Manhães, 2008).

According to Delgado (2011), the canebrakes are better distributed in the tropics, amid hot and rainy regions so that most species can develop at a temperature between $8^{\circ} \mathrm{C}$ and $36^{\circ} \mathrm{C}$. As said by Gonçalves (2018), in Brazil, there as 258 species listed, with 35 genus amongst the country's many different biomes, demonstrating diversity and potential, considering the different species and their different applicabilities.

Bamboos are anatomically constituted by a stalk like stem with epidermis, cortex, vascular cylinder and medulla, usually divided into nodes and internodes, forming the aerial part of the plant supporting the other structures and brokering with the roots. The stems come from the active side gems, present in the rhizome nodes, so that when the stems are in the early stages, the buds emerge, already having a definite diameter, but at the apex are funneled with a growth. which can be between $20 \mathrm{~cm}$ and $30 \mathrm{~m}$, or more. The leaf blades also make up the bamboos, having different morphologies and functions, like the stalk leaves, rhizome cataphils or the leaves of the branches. As well as rhizomes and roots which together form the underground bamboo 
system, rhizomes being responsible for the production of new stalks and roots, shoot support, nutrient storage and transport. As for the roots, they are mostly adventitious and serve to pin the plant to the ground, absorbing water and nutrients, thus being essential for plant survival(Luis et al., 2017).

It is important to mention that, as pointed out by Watanabe (2016), the bamboos with monopodial rhizome feature sprawling stems and sympodial ones have clustered stalks. He still punctuates the stem septa as responsible for wind resistance, as well as make them support their own weight that, allied with the rest of its anatomical structure, determine their physical properties, serving to define the species for being cultivated in view of the result.

According to Manhães (2008) it is possible, but difficult, the sexual spread ie, by the seed, because of sporadic flowering periods and / or lack of seed vigor and viability. The asexual spread is made by branches, buds, stalks and rhizomes, generating seedlings in varying numbers and within a few months.

As stated by Gonçalves (2018) the fast growth and easy regeneration ensure a shelf life of more than 30 years for the clump and replanting being unnecessary. The author still points out regular extraction techniques that allow the emergence of new individuals like removing half of the mature stems, that being, conscious management. In this regarde, Afonso (2011) states that in general, among bamboo species, plantations take between 5 and 7 years to settle, but from its third year it is possible to collect both the stem and the bud.

In Gonçalves' (2018) view, the bamboo can be managed to become a family farming option upon correct techniques in consortium with other cultures. In another sense, Almeida (2016) shows a biotechnological vision with industrialization, producing profitable value-added goods and creating jobs at the regional scale, that is, the bamboos influencing the social and productive chain.

As bamboo Applications, Manhães (2008) lists that agriculture favors the transport of water as a tubular structure and as biomass, there is a lot of efficiency in getting hydrogen, as well as coal with pyrolysis production, not to mention cellulose production and durable and quality paper. The author also cites the use as plywood for walls and floors, as well as raw material in the manufacture of furniture and in the construction of housing with price and time reduction, in agreement with Almeida (2016), who also looks at glued laminated bamboo, the slats and the moorings. Manhães (2008) adds that we can generate decoration artifacts and landscaped objects with bamboo, as well as musical instruments, tanks and nets.

Another featured application listed by Manhães (2008) is in cooking, being the nutrient-rich that bamboo is, it can ensure food and nutritional security as well as prevent cardiovascular disease and cancer, lowering cholesterol and blood pressure. Watanabe (2016) reports the millenary practice of consuming both shoots and bamboo leaves in Asian countries and their exponents.

In accordance with Watanabe (2016), there are between 50 and 60 species that produce edible bamboo shoots, these include: Bambusa balcooa, $B$. bambos, $B$. vulgaris, B. multiplex, B. oldhamii, $B$. tulda, B. tuldoides, B. vulgaris, Dendrocalamus asper, $D$. giganteus, $D$. hamiltonii, $D$. hookerii, $D$. latifera, $D$. latiflorus, $D$. longispathus, $D$. merrillianus, $D$. sikkimensis, $D$. strictus, Melocanna baccifera, Melocanna baccifera, Phyllostachys aurea, P. edulis, $P$. bambusoides, $P$. pubescens e Thyrsostachys siamensis.

. And when dealing with this processing it is necessary to know the nutritional compositions being ingested as well as the viable processing.

Nutritional composition of bamboo shoots:

According to Brito (2013), bamboo shoots resemble palm hearts and asparagus regarding the nutrients offered to their consumers. In this sense, Costa (2014), besides comparing the nutritional value, he also points out that within the food industry, bamboo has an advantage over palm hearts because it is not necessary to kill the plant for its harvest, not to mention the ease of being packed and kept. The nutritional values found by Costa (2014) are observed in Chart 1.

After testing and analysis of canning sprouts in 5\% vinegar solution, Tomielis et al. (2017) made the characterization culminating in the knowledge of the physicochemical composition of four species of bamboo (Chart 2)

The results found by Tomielis et al. (2017) point to safe cyanide levels and adequate $\mathrm{pH}$ to inhibit the proliferation of bacteria of the species Clostridium botulinum. Chart 2 also points to the difference in nutritional composition among the species studied, for example in the case of fibers which was $5.71 \%$ ( $B$. vulgaris var. Vittata) to $47,56 \%$ ( $P$. aurea). For the authors, these results encourage the consumption of bamboo shoots and assist in the choice of species, depending on the required fees, that is, bamboo can be seen as functional food, because its portion would have much of what is recommended to eat daily.

According to Watanabe (2016) shoots with only one harvest day have a creamy yellow color, having strong odor and taste and several processes are listed for consumption, as dehydration, canned, boiled or as an ingredient in beverages.

The author also explains that the flavor varies according to the presence in more or less of total sugars and total amino acids to make the product more attractive and sweet or give bitterness as in the case of tannins. Cyanogenic glycosides such as 
taxifillin and homogentisic acid cause the pungent taste, are also found in other species.

The consumption of bamboo sprout can be made fresh or processed, canned fresh or processed, canning ranging from in brine to likewise, it can be fermented or dehydrated as stated by Tomielis et al. (2017)

Chart 1. Comparison between the nutritional composition of bamboo shoots and juçara heart of palm.

\begin{tabular}{|l|c|c|c|c|c|c|c|c|c|}
\hline \multirow{2}{*}{$\begin{array}{c}\text { Composition } \\
(\%)\end{array}$} & \multicolumn{4}{|c|}{ Bambusa } & \multicolumn{3}{c|}{ Dendrocalamus } & $\begin{array}{c}\text { Juçara heart } \\
\text { of palm }\end{array}$ \\
\cline { 2 - 11 } & vulgares & tuldoides & vittata & nutans & beecheyana & giganteus & asper & latiflorus & \\
\hline Crude protein & 2,98 & 2,27 & 2,54 & 4,37 & 4,20 & 3,60 & 2,80 & 3,16 & 2,18 \\
\hline Grease & 0,27 & 0,23 & 0,25 & 0,37 & 0,48 & 0,38 & 0,34 & 0,21 & 2,51 \\
\hline Fibers & 0,57 & 0,85 & 0,72 & 0,73 & 0,75 & 0,55 & 0,90 & 0,66 & 0,99 \\
\hline Ashes & 0,91 & 0,95 & 0,91 & 0,88 & 0,90 & 0,93 & 0,99 & 0,83 & 1,34 \\
\hline Starch & 0,93 & 0,53 & 1,10 & 0,70 & 0,50 & 1,20 & 0,28 & 0,50 & - \\
\hline $\begin{array}{l}\text { Reducing } \\
\text { sugars }\end{array}$ & 1,02 & 1,00 & 0,95 & 1,24 & 1,31 & 1,25 & 2,61 & 1,52 & 0,55 \\
\hline Total sugar & 1,30 & 1,25 & 1,10 & 1,30 & 1,61 & 1,31 & 3,38 & 1,76 & 1,13 \\
\hline Tannin & 0,04 & 0,04 & 0,04 & 0,03 & 0,03 & 0,41 & 0,14 & 0,05 & 0,15 \\
\hline $\begin{array}{l}\text { Hydrocyanic } \\
\text { acid(ppm) }\end{array}$ & 153 & 324 & 435 & 673 & 117 & 435 & 583 & 295 & 10 \\
\hline Humidity & 93,00 & 93,80 & 93,26 & 91,27 & 91,45 & 92,00 & 90,13 & 95,53 & 90,81 \\
\hline pH & 5,60 & 5,40 & 5,50 & 5,70 & 6,70 & 5,75 & 5,95 & 5,70 & 5,85 \\
\hline
\end{tabular}

Source: Adapted from Costa (2017)

The authors are still concerned about the sensory quality of the final marketed product, that is, for them the texture, taste and aroma are directly linked to the shape of the processing so that, heat treatment and acidification can be used as steps to grant softness and prevent the development of microorganisms

Costa (2014) lists some procedures, like removing the bracts and even using vacuum packs are suggested for better conservation during industrial logistics. For Watanabe (2016) procedures such as thin slices and cooking are essential to remove toxins before consumption, ie, heat treatment is essential for canning to ensure the quality of the generated product.
To have control of the final product Watanabe (2016) recommends packing and cooling in order to decrease the respiration rate of the bud avoiding nutritional losses. Watanabe (2016) mentions that in several countries, products have been developed with nutritional variation, which have higher added value, such as sweet, spicy sauce, cookies and others from bamboo shoots. The bamboo can still be an ingredient in meat products, drinks and sauces. Another possibility is the shoot paste that was developed by Watanabe (2016) with a taste of fine herbs and a strong root that is fit for consumption in order to generate new product possibilities.

Chart 2. Physical and chemical composition of bamboos (Bambusa vulgaris, B. vulgaris var. Vittata, B. multiplex and Phyllostachys aurea) after canning processing.

\begin{tabular}{|c|c|c|c|c|c|}
\hline & unity & B. vulgaris & B. vulgaris var. Vittata & B. multiplex & P. aurea \\
\hline Humidity & g 100g' & $82,24 \pm 1,80 \mathrm{c}$ & $92,29 \pm 0,50 \mathrm{a}$ & $20,01 \pm 0,01 b$ & $87,00 \pm 0,20 \mathrm{~b}$ \\
\hline $\mathrm{pH}$ & $-\log [\mathrm{H}+]$ & $5,98 \pm 0,02 b$ & $1,10 \pm 0,3 \mathrm{a}$ & $6,07 \pm 0,01$ a 6,16 & $6,16 \pm 0,03 a$ \\
\hline Titratable acidity & $\mathrm{mL} \mathrm{NaOH}$ & $0,85 \pm 0,10 \mathrm{c}$ & $1,10 \pm 0,3 \mathrm{a}$ & $0,80 \pm 0,3 c$ & $0,95 \pm 0,1 b$ \\
\hline Ashes & $\mathrm{g} \mathrm{100g^{1 }}$ & $6,71 \pm 0,20 \mathrm{~b}$ & $24,27 \pm 0,06 \mathrm{~b}$ & $5,84 \pm 0,10 \mathrm{c}$ & $6,97 \pm 0,20 \mathrm{~b}$ \\
\hline Glycides & g 100g1 & $53,48 \pm 0,02 a$ & $24,27 \pm 0,06 b$ & $20,86 \pm 0,01 \mathrm{~b}$ & $9,84 \pm 0,02 c$ \\
\hline Protides & ${\mathrm{g} 100 \mathrm{~g}^{1}}^{1}$ & $10,70 \pm 0,21 \mathrm{~b}$ & $13,55 \pm 0,10 \mathrm{a}$ & $14,32 \pm 0,34 \mathrm{a}$ & $7,75 \pm 0,20 \mathrm{c}$ \\
\hline \begin{tabular}{|l} 
Lipids \\
\end{tabular} & g 100g-1 & $13,07 \pm 0,20 \mathrm{c}$ & $44,09 \pm 0,20 \mathrm{a}$ & $13,97 \pm 0,50 \mathrm{c}$ & $27,89 \pm 0,40 \mathrm{~b}$ \\
\hline Fibers & ${\mathrm{g} 100 \mathrm{~g}^{1}}$ & $16,04 \pm 0,60 \mathrm{~b}$ & $5,71 \pm 0,30 \mathrm{c}$ & $45,00 \pm 0,40 \mathrm{a}$ & $47,56 \pm 1,01 \mathrm{a}$ \\
\hline Total Phenolics & $\mathrm{mg} \mathrm{100g^{1 }}$ & $20,00 \pm 0,01 \mathrm{a}$ & $22,61 \pm 0,02 \mathrm{a}$ & $09,50 \pm 0,01 \mathrm{~b}$ & $09,81 \pm 0,01 \mathrm{~b}$ \\
\hline Total cyanide & $\mathrm{mg} \mathrm{100g^{1 }}$ & $28,00 \pm 0,01 \mathrm{a}$ & $20,00 \pm 0,01 \mathrm{~b}$ & $20,01 \pm 0,01 \mathrm{~b}$ & $18,22 \pm 0,01 \mathrm{~b}$ \\
\hline
\end{tabular}

Equal lowercase letters in the columns indicate that there is no statistical difference at the $5 \%$ probability level.

Source: Adapted from Tomielis et al. (2017). 


\section{Conclusion}

Given all the data analyzed and the information presented, the horizons for bamboo shoot processing with its vast potential in the food business, by the appropriate techniques, results in various high nutritional and value products in general and according to the chosen processing, it is possible to increase the added value.

\section{References}

AFONSO, D. G. Bambu nativo (Gradua spp.): Alternativa de desenvolvimento econômico e sustentável para o Estado do Acre. 49f. (Trabalho de Conclusão de Curso) - Universidade Federal do Paraná, Curitiba,Brasil, 2011.

ALMEIDA, J. G. de. Potencialidades do bambu. Sustentabilidade em Debate, 7: 178-195, 2016.

BRITO, J. S. de. Utilização do broto de bambu como possibilidade de diversificação alimentar no município de Taquara/RS. 2013. 51f. (Trabalho de Conclusão de Curso) - Universidade Federal do Rio Grande do Sul, São Francisco de Paula, Brasil, 2013.

COSTA, R. de S. M. da. O bambu: potencialidades técnicas e sociais e a política de incentivo ao manejo sustentado. 142f. (Dissertação de Mestrado) Universidade Federal Fluminense, Niterói, Brasil, 2014.

DELGADO, P. S. O bambu como material ecoeficiente: caracterização e estudos exploratórios de aplicações. 67f. (Dissertação de Mestrado) Universidade Federal de Ouro Preto, Ouro Preto, Brasil, 2011.

GONÇALVES, D. Bambu é alternativa de renda na produção familiar. 2018. https://www.embrapa.br/busca-de-noticias/-

/noticia/34230725/bambu-e-alternativa-de-renda-naproducao-familiar.

LUIS, Z. G.; NOGUEIRA, J. S.; RIBEIRO, D. G.; SCHERWINSKI-PEREIRA, J. E. Caracterização anatômica dos órgãos vegetativos de bambu (Poaceae, Bambusoideae). In: DRUMOND, P. M.; WIEDMAN, G. (Org.). Bambus no Brasil: da biologia à tecnologia. Instituto Ciência Hoje, Rio de Janeiro, Brasil. p. 42-59. Em 2017.

MANHÃES, A. P. Caracterização da cadeia produtiva do bambu no Brasil: abordagem preliminar. $32 f$. (Trabalho de Conclusão de Curso) - Universidade Federal Rural do Rio de Janeiro, Seropédica, Brasil, 2008.

BRASIL. Lei $\mathrm{n}^{\mathrm{a}}$ 12.484, de 08 de setembro de 2011. Dispõe sobre a Política Nacional de Incentivo ao
Manejo Sustentado e ao Cultivo do Bambu e dá outras providências. Diário Oficial da União, Seção 1, p. 1. Brasília: 2011.

TOMIELIS, I. P.; BRITO, V. H. dos S.; CEREDA, M. P. Potencial de uso alimentar de diferentes espécies de bambus. In: DRUMOND, P. M.; WIEDMAN, G. (Org.). Bambus no Brasil: da biologia à tecnologia. Instituto Ciência Hoje, Rio de Janeiro, Brasil. p. 382-391. Em 2017.

WATANABE, L. B. Desenvolvimento e caracterização de pasta de broto de bambu (Dendrocalamus asper). 95f.(Dissertação de Mestrado) - Universidade Federal de Santa Catarina, Florianópolis, Brasil, 2016. 